\title{
Strengthening Pancasila Values Through Karangtaruna Activities in Wieorugunan Village in Pandemi Covid 19
}

\author{
Suyahman \\ Program Studi PPKn Univet Bantara Sukoharjo, Jawa Tengah, Indonesia \\ suyahman.suyahman@yahoo.com
}

\section{Article History}

accepted 23/03/2021

approved 10/04/2021

published 20/04/2021

\begin{abstract}
The subject matter of the research was formulated: What is the strengthening of Pancasila values through Karangtaruna activities in Wirogunan Village, Kartasura District, Sukoharjo Regency during the Covid 19 pandemic. Research subjects: Karangtaruna management and members, and the objects are Pancasila values and Karangtaruna activities. Data collection methods: interviews and documentation. Data analysis was carried out by qualitative analysis. The results of the research were based on the results of interviews conducted with the management and members of the Karangtaruna group. Information was obtained: strengthening Pancasila values through Karangtaruna activities carried out by: 1. Religious values carried out by studying the Koran. 2. Human values: providing food and drink for residents who are self-isolating, 3. Unity value: maintaining a portal to monitor the exit of residents in an effort to anticipate the transmission of the Covid 19 virus, 4. Democratic value: regular meetings held by deliberation and consensus, 5 The value of fairness: treating all members and administrators fairly. The conclusion is that the strengthening of Pancasila values through Karangtaruna activities in Wirogunan Village, Kartasura District, Sukoharjo Regency is carried out by applying Pancasila values in all Karangtaruna activities.
\end{abstract}

Keywords: Pancasila values and karngtaruna activities

\begin{abstract}
Abstrak
Pokok permasalahan penelitian dirumuskan: Baimanakah penguatan nilai-nilai pancasila melalui kegiatan karangtaruna di desa Wirogunan Kecamatan Kartasura Kabupaten Sukoharjo pada masa pandemic covid 19. Jenis penelitiannya adalah deskriptif kualitatif. Subjek penelitiannya: pengurus dan anggota karangtaruna, dan objeknya adalah nilai-nilai pancasila dan kegiatan karangtaruna. Metode pengumpulan datanya: wawancara dan dokumentasi . Analisis data dilakukan dengan analisis kwalitatif. Hasil penelitian brdasarkan hasil wawancara yang dilakukan terhadap pengurus dan anggota karangtaruna diperoleh informasi: penguatan nilai-nilai pancasila melalui kegiatan karangtaruna dilakukan dengan: 1. nilai religius dilakukan dengan kegiatan kajian al quran . 2. Nilai kemanusiaan: memberikan makan dan minum bagi warga yang melakukan isolasi mandiri, 3. Nilai persatuan: menjaga portal untuk memantau keluiar masuknya warga dalam upaya antisipasi penularan virus Covid 19, 4. Nilai demokrasi: adanya rapat rutin dilakukan secara musyawarah mufakat, 5. Nilai keadilan: memperlakukan semua anggota dan pengurus secara adil, . Simpulan bahwa penguatan nilai-nilai pancasila melalui kegiatan karangtaruna di desa Wirogunan Kecamatan Kartasura Kabupaten Sukoharjo dilakukan dengan menerapkan nilai-nilai pancasila pada semua kegiatan karangtaruna.
\end{abstract}

Kata Kunci: nilai-Nilai Pancasila dan kegiatan karangtaruna

Social, Humanities, and Education Studies (SHEs): Conference Series https://jurnal.uns.ac.id/shes

p-ISSN 2620-9284 e-ISSN 2620-9292 


\section{PENDAHULUAN}

Fenomena banyaknya tokoh masyarakar, sebagian ASN, sebagian pejabat, sebagian pelajar dan mahasiswa yang tidak hapal dengan mengucapkan teks pancasila dan diviralkan adalah sangat naïf sekali, semestinya tidak terjadi hal yang demikan. Mensikapi hal ini tidak perlu dicari kambing hitamnya akan tetapi harus dicarikan solusinya. Jika hal ini dibiarkan 10 atau 20 tahun ke depan bias saja pancasila akan diluapkan sehingga mengancam keberadaan pancasila sebagai dasar dan ideology Negara kesatuan republic Indonesia. Jika cdemikian yang terjadi maka buburlah NKRI yang dibangun dengan perjuangan mengorbankan jiwa raga.

Mensikapi hal tersebut yang perlu dicari adalah akar masalahnya mengapa terjadi demikian? Secara factual banyak factor penyebabnya diantaranya kurangnya para ASN, Pejabat, pelajar dan mahasiswa dibiasakan untuk mengucapkan teks pancasila sebelum dan sesudah melakukan aktivitasnya. Demikian juga adanya pengaruh HP dengan lebih intensif mengakses Youtube, WA, Tik tok yang lebih banyak kurang mendidikan nilai-nilai pancasila.

Dengan kondisi yang demikian yang utama dilakukanpembentengan jati diri anak bangsa adalah para remaja yang nota bene menjadi generasi penerus cita-cita perjuangan bangsa. Eksistensi remaja harus dikelola secara serius dengan mengedepankan aktualisasi nilai-nilai pancasila dalam kehidupan sehari-hari.

Karangtaruna yang nota bene menjadi wadah berorganisasi bagi para remaja guna menanamkan dan menginternalisasikan benuh-benih nilai-nilai pancasila saat ini mulai tergerus arus globalisasi. Artinya kegiatan karang taruna saat ini sudah mulai terkena virus globalisasi, sehingga jika dibiarkan maka dampaknya akan semakin parah karena iti harus dicarikan solusinya. Upaya mencari solusi harus dicari akar masalahnya sehingga pemberian solusi dapat efektif dan efisien.

Pada penelitian melihat fakta dilapangan banyak sikap, perilaku dan perbuatan remaja baik sebagi pengurus maupun anggota karangtaruna di desa wirogunan, kecamatan kartasura, kabupaten sukoharjo kurang mencerminkan nilai-nilai pancasila dianatranya: membuat keonaran, miras, menggunakan obat-obatan terlarang, pergaulan bebas, hingga melakukan tindakan yang kurang terpuji. Melihat fatka yang demikian jika dibiarkan maka kehidupan masyarakat bias tidak nyaman, aman dan damai. Karena itu harus dicarikan pemecahannya.

Penelitian ini berfokus pada tugas, pokok dan fungsi karangtaruna sebagai wahana untuk membangun sikap,perilaku dan perbuatan yang mencerminkan nilai-nilai pancasila. Tujuan penelitian ini adalah mendeskripsikan penguatan nilai-nilai pancasila bagi remaja melalui karangtaruna di desa wirogunan, kecamatan kartasura, kabupaten sukoharjo.

\section{Teori}

\section{Pemahaman Nilai-Nilai Pancasila}

Nilai-nilai Pancasila merupakan pegangan dasar bagi masyarakat Indonesia dalam kehidupan berbangsa dan bernegara. Segala keputusan, kebijakan, dan aktivitas yang dilakukan baik oleh pemerintah maupun masyarakat Indonesia harus berpedoman pada Pancasila. Fungsi Pancasila memang sekrusial itu karena pada dasarnya dia adalah rujukan dari segala aktivitas kita sebagai bangsa dan negara.(Asmaroini, 2016)

Menurut Suteng SS , 2020. Jika dilihat dari segi nilai dasarnya, Pancasila mengandung dua kelompok besar nilai yaitu nilai subjektif dan nilai objektif. Selain itu, terdapat pula nilai-nilai yang terkandung di dalam lima sila Pancasila. Nilai objektif artinya adalah nilai-nilai yang secara universal diterima dan relevan dengan kondisi social yang ada saat ini. Nilai-nilai objektif selalu dapat diterima di segala tempat karena berlaku secara universal.(Syamsudin, 2019) Pancasila mengandung nilai universal yang selalu relevan di segala tempat, seperti nilai kemanusiaan dan nilai keadilan sosial. Kedua nilai ini selalu revelan dimanapun kita berada. Tidak ada negara 
atau bangsa yang secara sadar mengakui bahwa dia tidak menyukai keadilan atau kemanusiaan. Hal ini terjadi karena nilai-nilai diatas didasarkan pada hak asasi manusia yang universal. Hak asasi manusia yang universal dianggap sebagai hak melekat tiap manusia atau god given rights yang tidak dapat diganggu-gugat.

Berbeda dengan nilai objektif, nilai subjektif Pancasila meliputi nilai-nilai yang ada karena pencetusnya menyukai ide tersebut. Nilai subjektif umumnya tidak berlaku secara universal, namun sangat tergantung wilayah dimana nilai tersebut berlaku.(Yudistira, 2016) Contohnya adalah nilai kesopanan yang berbeda antara di negara Asia dengan negara Eropa. Nilai yang ada pada Pancasila berasal dari kristalisasi falsafah kehidupan bangsa Indonesia yang telah diobservasi dan dimusyawarahkan oleh para pendiri bangsa kita. Nilai seperti ketuhanan diangkat kedalam Pancasila karena memang semenjak dahulu kala, masyarakat Indonesia sangat religius dan menempatkan agama didalam kehidupannya sehari-hari. Selain itu, nilai seperti permusyawaratan juga mewakili bangsa Indonesia yang senang berdiskusi dan senantiasa ingin menghasilkan keputusan yang menguntungkan semua pihak. (Aminullah, 2015) Hal ini tidak dapat dilakukan dengan cara voting. Oleh karena itu, keputusan tingkat tinggi yang krusial idealnya dilakukan dengan cara musyawarah untuk mencapai mufakat.

Menurut, Wasithohadi, 2019, Pancasila sebagai dasar filsafat Negara disamping memiliki nilai subjektif dan objektif juga memiliki nilai-nilai Pancasila yang melekat pada tiap silanya. Selain berasal dari bunyi silanya, nilai yang ada juga dapat di maknai dari simbol kelima sila yang ada di Pancasila.

\section{a. Sila Pertama: Ketuhanan Yang Maha Esa}

Aspek religius merupakan nilai yang melekat dan memegang peranan penting bagi bangsa Indonesia Sila pertama memiliki nilai religius dimana bangsa Indonesia diharapkan percaya kepada konsep ke-Tuhan-an Yang Maha Esa, dimana disitu terdapat Tuhan yang maha esa. Selain itu, sila pertama ini juga memiliki nilai ketaqwaan dimana bangsa Indonesia sudah selayaknya bertaqwa kepada tuhan serta kepercayaan/agama yang dianutnya.(Anggraini et al., 2020)

Seseorang dapat dikatakan sudah menjunjung tinggi nilai ketuhanan jika dia bertaqwa kepada tuhan yang maha esa sesuai dengan agama atau kepercayaan yang dianutnya. Selain itu, kita juga harus menghormati orang-orang yang memiliki agama dan kepercayaan yang berbeda. Kita tidak boleh memaksa mereka untuk mengikuti kepercayaan kita.

Dalam menjalankan sila yang pertama, kita harus menyadari bahwa agama dan kepercayaan adalah suatu hal personal antara manusia dengan tuhan-nya. Oleh karena itu, aspek yang paling penting adalah bagaimana kita dapat bertoleransi dalam bertuhan dan beragama.

\section{b. Sila Kedua: Kemanusiaan yang Adil dan Beradab}

Setiap manusia memiliki hak asasi yang melekat pada dirinya dan tidak dapat diganggu gugat Sila kedua dengan bahasa kemanusiaan yang adil dan beradab memiliki nilai kemanusiaan dan keadilan bagi manusia. Pada dasarnya, sila ini membahas mengenai hak asasi yang dimiliki oleh setiap manusia di dunia, tidak hanya orang Indonesia saja.

Seseorang dapat dikatakan memegang teguh nilai kemanusiaan jika setiap tindakan dan keputusan yang diambil menjaga martabat orang lain, tanpa merendahkan ataupun merugikan mereka.(Octavian, 2018) Selain itu, sikap adil juga menjadi salah satu tolok ukur dari penerapan nilai ini dalam kehidupan sehari-hari. Orang yang berpegang teguh pada nilai kemanusiaan akan senantiasa menghormati orang lain, adil dalam berfikir dan bertindak, menghargai orang lain, serta memiliki adab yang baik dalam memandang dan memperlakukan orang lain. 


\section{c. Sila Ketiga: Persatuan Indonesia}

Jiwa nasionalisme dan bela negara merupakan hal yang penting dalam mewujudkan persatuan Indonesia Sila ketiga ini mengandung nilai persatuan seluruh bangsa Indonesia. Sila ini memiliki makna bahwa bangsa Indonesia, dimanapun dia berada, memiliki kewajiban untuk terus menjaga persatuan bangsa Indonesia.(Chairiyah, 2014) Jangan sampai ada tindakan yang baik sengaja maupun tidak sengaja dilakukan untuk memecah belah bangsa.

Secara tidak langsung, sila ketiga ini juga memiliki nilai multikulturalisme dan nilai toleransi. Tidak dapat dipungkiri bahwa Indonesia merupakan negara dengan berbagai macam suku dan budaya yang berbeda-beda. Oleh karena itu, untuk mencapai persatuan, kita harus mampu menerima perbedaan tersebut dan menjadikannya kekuaan. Persis seperti semboyan kita, Bhinneka Tunggal Ika. Seseorang dapat dikatakan sukses dalam mengaplikasikan nilai persatuan Indonesia jika dia mau menghormati perbedaa, cinta tanah air, memiliki jiwa bela negara, rela berkorban demi bangsa, serta mau mengesampingkan keinginan pribadinya demi kepentingan Bersama.

\section{d. Sila Keempat: kerakyatan yang dipimpin oleh hikmat kebijaksanaan dalam permusyawaratan perwakilan}

Dalam bermusyawarah, kita harus senantiasa mementingkan kepentingan bersama dan hasil yang saling menguntungkan Sila keempat ini mengandung nilai permusyawaratan dan demokrasi dalam menentukan segala keputusan. Seperti yang sudah kita ketahui, bangsa Indonesia sangat menyukai berdiskusi jika terdapat suatu perselisihan, agar dapat ditemukan solusi yang menguntungkan bagi semua pihak.

Nilai sila ini menunjukkan bahwa negara Indonesia diselenggarakan berdasarkan demokrasi. Semua keputusan yang menyangkut hajat hidup orang banyak disetujui lewat musyawarah mufakat yang melibatkan tokoh-tokoh yang sudah kita pilih untuk mewakili kita. Dengan adanya system seperti ini, diharapkan segala keputusan yang diambil menguntungkan bagi semua pihak. Seseorang dapat dibilang memegang teguh nilai permusyawaratan ketika dia selalu bermusyawarah dengan semua pemangku kepentingan dalam mengambil keputusan, anti-kekerasan, mengutamakan kepentingan bersama diatas kepentingan golongan atau pribadi, serta ma menghargai perbedaan pendapat.(Kariyadi \& Suprapto, 2017)

\section{e. Sila Kelima: keadilan sosial bagi seluruh rakyat Indonesia}

Masih banyak saudara kita yang belum mendapatkan keadilan sosial di negara Indonesia Sila kelima ini mengandung nilai keadilan sosial yang artinya, seluruh rakyat Indonesia berhak mendapatkan keadilan dalam kehidupan berbangsa dan bernegara. Keadilan sosial ini tidak terbatas pada aspek sosial, tetapi meliputi pula aspek ekonomi, politik, dan aspek budaya.

Seseorang dapat dikatakan memegang teguh nilai keadilan jika dia mau menyelesaikan kewajibannya sebagai warga negara sembari menuntut hak nya serta mau dan mampu untuk bersikap adil kepada diri sendiri dan orang lain.(Adha \& Susanto, 2020) Selain itu orang yang menganut nilai keadilan sosial juga harus mau untuk menghargai kinerja orang lain, rela bekerja keras, mau untuk berhemat dan tidak berfoya-foya, mengutamakan pemerataan kesejahteraan di masyarakat, dan tidak melakukan tindakan-tindakan yang dapat meningkatkan jurang ketidaksetaraan.

Kelima nilai pancasila tersebut wajib disosialisasikan pada seluruh lapisan masyarakat agar dapat diimplementasikan seluruh warga Negara dalam hidup bermasyarakat, berbangsa dan bernegara dalam kehidupan sehari-hari.(Aminullah, 2015)

Upaya untuk mensosialisasikan dan membudayakan nilai-nilai pancasila menjadi tanggung jawab 3 pilar pendidikan : pertama keluarga sebagai lembaga pendidikan in-formal, kedua sekolah sebagai lembaga pendidikan formal, dan masyarakat sebagai lembaga pendidikan non-formal. (Damanhuri et al., 2016) Dalam 
upaya mensosialisasikan dan membudayakan nilai-nilai pancasila masing-masing lingkungan pendidikan memiliki peran dan usaha yang tidak. Karena para pemerannya berbeda-beda tugas, pokok dan fungsinya. (Ariif, 2011).

\section{Upaya Menananmkan Nilai-Nilai Pancasila}

Menanamkan nilai-nilai pancasila pada generasi muda hukumnya wajib dilakukan oleh keluarga, sekolah dabn masyarakat. Di era global seperti saat ini tantangan dalam menanamkan nilai-nilai pancasila semakin kompleks. Banyak ditemukan di media social penyimpangan nilai-nilai pancasila yang dilakukan oleh generasi muda. Fenomena ini sangat memprihatinkan dan bahkan bias menjadi ancaman serius bagi keutuhan bangsa dan Negara ke depannya. Ironisnya banyak Negara yang memuji kehebatan nilai-nilai pancasila dalam kehidupan berbangsa dan bernegara.

Melihat kenyataan seperti ini maka harus diupayakan secara serius saranha untuk menanamkan nilai-nilai pancasila. Menurt Haris 2020, ada 3 strategi yang dapat dilakukan dalam rangka menanamkan nilai-nilai pancasila baik dilakukan keluarga, masyarakat maupun sekolah. Ketiga strategi yang dimaksud adalah: pertama melalui pembiasaan, keua melalui keteladanan dan ketiga melalui pemberian penghargaan dan hukuman.

\section{Konsep dasar Karangtaruna}

Berdasarkan sejarah yang ada karang taruna lahir pada 26 September 1960 di sebuah daerah di Jakarta. Gerakan ini dilakukan sebagai wujud semangat dan kepedulian kamu muda untuk membantu meningkatkan kesejahteraan masyarakat. Kepedulian tersebut diwujudkan melalui sebuah organisasi pemuda yang banyak melakukan kegiatan positif. Kegiatan yang banyak dilakukan antara lain, kesenian, olahraga, rekrasi, pengajian, dan kegiatan pendidikan lain baik di bidang agama atau secara umum.

Karang taruna melakukan kegiatan tersebut diperuntukkan bagi anak-anak yang tidak sekolah, yatim piatu, putus sekolah, dan lain-lain yang dirasa banyak kegiatan yang kurang manfaat. Para pemuda berinisiatif untuk melakukan kegiatan melalui karang taruna. Karang taruna terus berkembang dan menyebar luas keseluruh bagian Indonesia. seperti yang kita tahu saat ini sudah sampai hingga wilayah pedesaan. Banyak kegiatan yang dilakukan yang bermanfaat bagi masyarakat sekitar.

Karang taruna memiliki landasan hukum yang jelas yaitu keputusan menteri sosial RI nomor13/HUK/EP/1981 tentang susunan organisasi dan tata kerja Karang Taruna. Peraturan ini mengatur tentang komponen kepengurusan yang ada dalam sebuah organisasi karang taruna. Banyak hal yang telah dilakukan organisasi ini dan kontribusinya sudah jelas terlihat dan banyak memberikan dampak yang baik. Perkembangan karammg taruna tak secepat dahulu namun karang taruna tetap ada di setiap daerah.

Terdapat beberapa definisi menurut beberapa ahli antara lain, sebagai berikut; Kamus Besar Bahasa Indonesia (KBBI) Karang taruna berasal dari kata dasar karang yang berarti tempat untuk menghimpun atau sebagainya. Taruna memiliki makna pemuda, sehingga dapat kita simpulkan bahwa karang taruna adalah tempat berkumpulnya para pemuda. Permensos RI tahun 2010 Pasal 1 Ayat 1 Karang taruna adalah organisasi sosial masyarakat yang dijadikan sebagai wadah dan salah satu sarana pengembangan setiap anggota masyarakat yang tumbuh dan berkembang atas dasar rasa tanggungjawab sosial yang berasal dari, oleh, dan untuk masyarakat itu sendiri terutama generasi muda. Direktorat Bina Karang Taruna Arti organisasi karang taruna adalah salah satu wadah perkumpulan di masyarakat yang berorientasi pada kegiatan sosial. Organisasi ini memiliki fungsi sebagai sarana partisipasi masyarakat dalam melaksanakan Usaha Kesejahteraan Sosial.

Berdasarkan pandangan karangtaruna di atas dalam penelitian ini disimpulkan bahwa 
Karang taruna adalah salah satu jenis organisasi kepemudaan di Indonesia yang dijadikan wadah untuk mengembangkan kemampuan atas dasar keasadaran dan tanggungjawab dalam suatu daerah khusunya di desa yang ia tempati.

Anggota karang taruna terdiri atas pemuda dan pemudi yang berusia 11 sampai dengan 45 tahun. Pengurus karang taruna yang berusia 17 hingga 35 tahun. Karang taruna memiliki berbagai kegiatan untuk mengembangakan kemampuan mereka.

Kegiatan dapat berupa kegiatan keagamaan, hari nasional, atau kegiatan sosial. Banyak daerah yang menyelenggarakan kegiatan di daerah-daerah secara rutin sehingga para pemuda memiliki kegiatan yang positif.

\section{Tugas pokok dan fungsi Karangtaruna}

Karangtaruna di desa Wirogunan kecamatan Kartasura kabupaten Sukoharjo dibentuk dengan tujuan: 1. Terwujudnya pertumbuhan dan perkembangan akan kesadaran atas sebuah tanggung jawab berkaitan dengan sosial. Setiap generasi muda menjadi anggota karang taruna dalam mencegah, menangkal, menanggulangi, dan mengantisipasi akan adanya berbagai masalah sosial. 2. Terbentuknya jiwa dan semangat berjuang bagi generasi muda anggota karang taruna yang trampil, berkepribadian, dan berpengetahuan. 3. Tumbuhnya potensi dan kemampuan generasi muda dalam melakukan kegiatan yang berkaitan denga karang taruna. 4 . Menjadikan generasi muda yang memiliki motivasu tinggi setiap untuk mampu menjalin sebuah toleransi, dengan hal tersebut diharapkan dapat menjadi perekat persatuan dalam keberagaman kehidupan bermasyarakat, berbangsa dan bernegara. 5 . Terjalinnya kerjasama antara generasi muda anggota karang taruna dengan masyatakat dan pemerintah dalam rangka mewujudkan dan meningkatkan taraf kesejahteraan sosial bagi masyarakat sekitar. 6. Terwujudnya kesejahteraan sosial yang meningkat bagi masyarakat atas segala hal yang dilakukan oleh karang taruna. Hal ini yang memungkinkan pelaksanaan segala fungsi sosialnya sebagai manusia. Mampu melakukan pembangunan yang mampu mengatasi masalah kesejahteraan sosial dilingkungannya. 7. Terwujudnya pembangunan kesejahteraan sosial generas muda yang menyeluruh. Karang taruna bersama pemerintah dan masyarakat lainnya, bersama-sama dengan pemerintah dan komponen masyarakat lainnya untuk menanggulangi berbagai masalah kesejahteraan sosial, baik yang bersifat preventif, rehabilitatif maupun pengembangan potensi generasi muda di lingkungannya.

Sedangkan manfraatnya dibentuknya karangtaruna di desa Wirogunan kecamatan Kartasura kabupaten Sukoharjo: 1. Menumbuhkan kesadaran generasi muda tentang taggungjawab kepada lingkungan, 2. Mewujudkan persatuan dan kesatuan generasi muda, 3. Terwujudnya kesejahteraan bagi kaum muda, 4. Terjalinnya kerjasama antar generasi muda dengan masyarakat untuk kesejahteraan bersama, 5. Menambah akrab antar generasi muda, dan 6. Menambah informasi terkait kegiatan yang dapat mengembangkan pribadi atau masyarakat umum.

Kemudian fungsi organisasi karangtaruna di desa Wirogunan kecamatan Kartasura kabupaten Sukoharjo : 1. Penyelenggara usaha dan kegiatan yang bertujuan untuk kesejahteraan sosial., 2. Penyelenggara pendidikan dan pelatihan yang ada di lingkungan sekitar., 3. Penyelenggara pemberdayaan masyarakat terutama fokus pada sasaran utama yaitu generasi muda dilingkunggannya secara komprehensif, terpadu dan terarah serta berkesinambungan., 4. Penyelenggara kegiatan pengembangan dan pelatihan dalam bidang kewirausahaan bagi generasi muda di lingkungannya, 5. Penanaman pengertian dan meningkatkan pemahaman generasi muda., 6. Penumbuhan dan pengembangan semangat kebersamaan, kekeluargaan, persahabatan, kesetiakawanan dalam satu wadsh yaitu NKRI., 7. Meningkatkan tingkat kreatifitas generasi muda untuk dapat mengikuti dan mengembangkan tanggung jawab sosial yang bersifat rekreatif, kreatif, edukatif, ekonomis produktif dan kegiatan praktis lainnya yang dapat dimanfaatkan untuk kepentingan masyarakat., 8. Menjadi rujukan, pendampingan, dan advokasi sosial bagi 
masyarakat yang mengalami permasalahan kesejahtrraan sosial. 9. Penguatan sistem komunikasi bagi lingkungan masyarakat., dan 9. Penyelenggara usaha-usaha pencegahan permasalahan sosial yang aktual. Tugas pokok Karangtaruna yaitu; 1. Belajar menanggulangi permasalahan yang ada di daerah , 2. Pengembangan potensi generasi muda

a. Kegiatan Karangtaruna

Karangtaruna di desa Wirogunan kecamatan Kartasura kabupaten Sukoharjo didalam menjalankan tugas pokok dan fungsinya membuat program kegiatan disesuaikan dengan kebutuhan dan kemampuan masyarakatnya. Beberapa kegiatan yang disusunnya mencakup: kegiatan di bidang keagamaan, kegiatan di bidang social, kegiatan di bidang seni dan olah raga, kegiatan di bidang keamanan serta kegiatan di bidang ideology dan wawasan kebangsaan. Kegiatan-kegiatan tersebut bersinergi dengan program-program yang dibuat pemerintah desa, sehingga sangat mendukung terwujudnya program desa secara optimal.

Pelaksanaan kegiatan karangtaruna bersifay fleksibel artinya selalu disesuaikan dengan kepentingan dan kebutuhan masyarakat desa, sehingga sangat mendukung pelaksanaan pembangunan desa di segala aspek dan bidangnya.

b. Organisasi Karangtaruna

Keanggotaan karangtaruna pada dasarnya bersifat sukarela namun demikian harus tetap memenuhi persyaratan sebagai berikut: Menerima segala aturan dan tujuan organisasi, Aktif mengikuti kegiatan organisasi, Apabila tidak mematuhi aturan bersedia mengundurkan diri dan Mengikuti pelatihan dasar tingkat desa.

Guna menjalankan roda organisasi secara efektif dan efisien , organisasi karangtaruna di desa Wirogunan kecamatan Kartasura kabupaten Sukoharjo dibentuk struktur organisasi yang susunan sebagai berikut: pelindung, penasehat, ketua, wakil ketua, sekretaris, wakil sekretaris, bendahara wakil bendahara, dilengkapi dengan seksi-seksi: keagamaan, social, seni dan olah raga, mental dan ieologi.

\section{Jenis Penelitian}

\section{METODE}

Penelitian ini termasuk jenis penelitian deskriptif kualitatif. Menurut Sugiyono, 2005 Penelitian kualitatif mengkaji perspektif partisipan dengan strategi-strategi yang bersifat interaktif dan fleksibel. Penelitian kualitatif ditujukan untuk memahami fenomena-fenomena sosial dari sudut padang partisipan. Dengan demikian arti atau pengertian penelitian kualitatif tersebut merupakan penelitian yang digunakan untuk meneliti pada kondisi objek. Alamiah dimana peneliti merupakan instrumen kunci. Sementara itu Sukmadinata, 2005 menjelaskan Dasar penelitian kualitatif merupakan konstruktivisme yang berasumsi bahwa kenyataan itu berdimensi jamak, interaktif dan suatu pertukaran pengalaman sosial yang diinterpretasikan oleh setiap individu. Peneliti kualitatif percaya bahwa kebenaran ialah dinamis dan dapat ditemukan hanya melalui penelaahan terhadap orang-orang melalui interkasinya dengan situasi sosial merekaPenelitian deskriptif kualitatif dalam penelitian ini dimakna sebagai suatu penelitian dengan mendeskripsikan suatu kondisi sekarang yang diproyeksikan pada situasi dan kondisi kedepan yang lebih baik.

\section{Waktu dan Tempat penelitian}

Penelitian dilakukan selama 3 bulan dimulai pada bulan januari sampai dengan maret tahun 2021, dengan mengambil lokasi penelitian Di Desa Wirogunan, Kecamatan kartasura kabupaten Sukoharjo, Provinsi jawa Tengah.

\section{Subjek dan objke penelitian}

Subjek penelitian ini yaitu anggota dan pengurus karangtaruna Di Desa Wirogunan, Kecamatan kartasura kabupaten Sukoharjo, Provinsi jawa Tengah, dan objek penelitiannya yaitu: nilai-nilai Pancasila dan Kegiatan Karangtaruna Di Desa Wirogunan, Kecamatan kartasura kabupaten Sukoharjo, Provinsi jawa Tengah. 


\section{Sumber Data}

Sumber data penelitian ini yaitu seluruh pengurus dan sebagian anggota karang taruna Di Desa Wirogunan, Kecamatan kartasura kabupaten Sukoharjo, Provinsi jawa Tengah sebanyak 50 orang yang terinci untuk selurih pengurus ada 15 orang dan untuk anggota diambil secara acak dari 125 orang diambil sebanyak 35 orang.

\section{Metode pengumpulan data}

Metode pengumpulan data menggunakan wawancara secara langsung dengan menggunakan instrument penelitian pedoman wawancara, angket dengan menggunakan instrument penelitian pedoman angket dan dolumentaisi dengan menggunakan instrument penelitian daftar list documenter yang berkaiatn dengan halhal yang diteliti.

\section{Validitas data}

Validitas data dilakukan dengan menggunakan trianggulasi sumbr data dan metode. Trianggulasi sumber data dilakukan dengan cara mengcroscek hasil wawancara pengurus karangtaruna dengan hasil wawancara para anggota karangtaruna, trianggulasi metode dilakukan dengan mengkroscek hasil penggunaan metode pengumpulan data antara wawancara dengan angket

\section{Teknik analisis data}

Teknik analisis data dilakukan dengan menggunakan teknik analisis kualitatif mngalir. Menurut Moleong, teknik analisis data ini terdiri dari 3 tahap yaitu: reduksi data, display data, dan vrifikasi data.

\section{HASIL DAN PEMBAHASAN}

Berdasarkan hasil wawancara dengan pengurus dan anggota karangtaruna Di Desa Wirogunan, Kecamatan kartasura kabupaten Sukoharjo, Provinsi jawa Tengah yang dilakukan pada tanggal 2 sampai 10 pebruari 2021 diperoleh informasi bahwa : aktualisasi nilai-nilai pancasila dirasakan lemah sehingga perlu diberikan penguatan. Hal ini dapat dilihat secara detail hasil wawancara dengan para pengurus dan anggota yaitu: banyak sikap, perilaku, dan perbuatan yang kurang mncrminkan nilai-nilai pancasila diantaranya: saat mendengar suara adzan masih main game dengan HP, memilih temnan bergaul dengan membeda-bedakan, membiarkan temannya membully teman lainnya, kurang menghargai pendapat orang lain dan tidak mau melaksanakan keputusan hasil rapat secara bertanggung jawab, berlaku tidak adil terhadap perlakuan teman-temannya.

Dengan melihat fakta yang demikian maka dilakukan pendapat melalui angket tentang bagaimana cara menguatkan nilai-nilai pancasila bagi para pengurus dan anggitanya. Hasil angket seperti tersebut dibawah ini:

\begin{tabular}{|l|l|l|l|}
\hline No & \multicolumn{1}{|c|}{ Pernyataan } & \multicolumn{2}{|c|}{ Jawaban } \\
\cline { 3 - 4 } & & Setuju & \multicolumn{1}{|c|}{$\begin{array}{l}\text { Tidak } \\
\text { Setuju }\end{array}$} \\
\hline 1 & $\begin{array}{l}\text { Setujukan jika banyak pengurus dan anggota sikap, perilaku, } \\
\text { dan perbuatannya bertentangan dengan nilai-nilai pancasila }\end{array}$ & 45 & 5 \\
\hline 2 & $\begin{array}{l}\text { Setujukan jika para pengurus dan anggotanya diberikan } \\
\text { epnguatan agar sikap,perilaku dan perbuatannya lebih banyak } \\
\text { mencerminkan nilai-nilai panacsila }\end{array}$ & 48 & 2 \\
\hline 3 & $\begin{array}{l}\text { Setujukan jika dalam memberikan penguatan dilakukan } \\
\text { melalui program kegiatan karangtaruna }\end{array}$ & 50 & 0 \\
\hline 4 & $\begin{array}{l}\text { Setujukan jika penguatan nilai religius dilakukan dengan } \\
\text { melalui kegiatan kajian alquran yang dilakukan tiap minggu } \\
\text { sekali }\end{array}$ & 46 & 4 \\
\hline
\end{tabular}




\begin{tabular}{|l|l|l|l|}
\hline 5 & $\begin{array}{l}\text { Setujukah jika penguatan nilai kemanusian dilakukan dengan } \\
\text { cara memberikan makanan pada warga yang melakukan isolir } \\
\text { mandiri karena reaktif covid -19 }\end{array}$ & 47 \\
\hline 6 & $\begin{array}{l}\text { Setujukah jika penguatan nilai persatuan dilakukan dengan } \\
\text { cara menjaga portal pintu masuk keluarnya ke desa dari orang } \\
\text { luar }\end{array}$ & $\begin{array}{l}\text { Setujukan jika penguatan nilai demokrasi dilakukan dengan } \\
\text { cara menghargai dan menghormati pendapat yang berbeda } \\
\text { saat rapat }\end{array}$ & 47 \\
\hline 8 & $\begin{array}{l}\text { Setujukan jika penguatan nilai keadilan dilakukan dengan cara } \\
\text { berlaku adil pada semua pengurus dan anggota karangtaruna }\end{array}$ & 50 & 3 \\
\hline 9 & $\begin{array}{l}\text { Setujukan jika pengurus dan anggota yang melakukan } \\
\text { pelanggaran terhadap sila-sila dalam pancasila diberikan } \\
\text { hukuman }\end{array}$ & 45 & 5 \\
\hline 10 & $\begin{array}{l}\text { Setujukan jika pengurs dan anggota karangtaruna dalam } \\
\text { sikap,perilaku, dan perbuatannya selalu menjadi keteladanan } \\
\text { bagi orang lain diberikan penghargaan }\end{array}$ & 45 & 5 \\
\hline 11 & $\begin{array}{l}\text { Setujukan jika cara member penguatan dilakukan dengan } \\
\text { pembiasaan, keteladanan, penghargaan dan hukuman }\end{array}$ & 46 & 4 \\
\hline 12 & $\begin{array}{l}\text { Setujukan jika pemberian penguatan melibatkan tokoh } \\
\text { agaman, tokoh masyarakat dan tokoh pemuda }\end{array}$ & 48 & 2 \\
\hline
\end{tabular}

Tabel 1. Angket hasil penelitian penguatan nilai-nilai pancasila melalui kegiatan karangtaruna Di Desa Wirogunan, Kecamatan kartasura kabupaten Sukoharjo, Provinsi jawa Tengah.

Berdasarkan tabel di atas tampak jelas bahwa penguatan nilai-nilai pancasila melalui kegiatan karangtaruna mutlak harus dilakukan dengan dimasukan ke dalam program kerja karangtaruna Di Desa Wirogunan, Kecamatan kartasura kabupaten Sukoharjo, Provinsi jawa Tengah. Dalam hal pemberian penguatan dilakukan dengan : pemberian pembiasaan, keteladanan, pengharagaan dan hukuman yang bersifat edukatif. Keterlibatan dalam memberikan penguatan yaitu berasal dari unsure: tokoh agaman, tokoh masyarakat, dan tokoh pemuda.

\section{SIMPULAN}

Berdasarkan hasil penelitian dan pembahasan dapat ditarik kesimpulan: bahwa penguatan nilai-nilai pancasila perlu dilakukan karena ditemukan banyaknya sikap, perilaku, dan perbuatan yang dilakukan remaja Di Desa Wirogunan, Kecamatan kartasura kabupaten Sukoharjo, Provinsi jawa Tengah bertentangan dengan nilai-nilai pancasila. Penguatan nilai-nilai pancasila dilakukan melalui karangtaruna dengan cara memasukan program-program kegiatan karang taruna yang memuat nilai-nilai pancasila serta dilakukan dengan cara pembiasaan, keteladanan, penghargaan dan hukuman bagi yang melanggarnya.

\section{DAFTAR PUSTAKA}

Adha, M. M., \& Susanto, E. (2020). Kekuatan Nilai-Nilai Pancasila Dalam Membangun Kepribadian Masyarakat Indonesia. Al-Adabiya: Jurnal Kebudayaan Dan Keagamaan. Https://Doi.Org/10.37680/Adabiya.V15i01.319

Aminullah. (2015). Inplementasi Nilai-Nilai Pancasila Dalam Kehidupan. Jurnal IImiah IKIP Mataram.

Anggraini, D., Fathari, F., Anggara, J. W., \& Ardi Al Amin, M. D. (2020). Pengamalan Nilai-Nilai Pancasila Bagi Generasi Milenial. Jurnal Inovasi IImu Sosial Dan Politik. Https://Doi.Org/10.33474/Jisop.V2i1.4945

Ariif, D. B. (2011). Pembudayaan Nilai-Nilai Pancasila Pada Warga Negara Muda Melalui Pendidikan Kewarganegaraan. Kongres Pancasila Ke-3. 
Asmaroini, A. P. (2016). IMPLEMENTASI NILAI-NILAI PANCASILA BAGI SISWA DI ERA GLOBALISASI. Citizenship Jurnal Pancasila Dan Kewarganegaraan. Https://Doi.Org/10.25273/Citizenship.V4i2.1077

Chairiyah. (2014). Revitalisasi Nilai-Nilai Pancasila Sebagai Pendidikan Karakter. Jurnal Pendidikan.

Damanhuri, D., Bahrudin, F. A., Legiani, W. H., \& Rahman, I. N. (2016). Implementasi Nilai-Nilai Pancasila Sebagai Upaya Pembangunan Karakter Bangsa. Untirta Civic Education Journal. Https://Doi.Org/10.30870/Ucej.V1i2.1890

Kariyadi, D., \& Suprapto, W. (2017). MEMBANGUN KEPEMIMPINAN BERBASIS NILAI-NILAI PANCASILA DALAM PERSPEKTIF MASYARAKAT MULTIKULTURAL. Citizenship Jurnal Pancasila Dan Kewarganegaraan. Https://Doi.Org/10.25273/Citizenship.V5i2.1560

Octavian, W. A. (2018). Urgensi Memahami Dan Mengimplementasikan Nilai-Nilai Pancasila Dalam Kehidupan Sehari-Hari Sebagai Sebuah Bangsa. Bhinneka Tunggal lka.

Syamsudin. (2019). Pancasila Sebagai Dasar Nilai IImu Pengetahuan. Journal Of Chemical Information And Modeling.

Yudistira. (2016). Aktualisasi \& Implementasi Nilai-Nilai Pancasila Dalam Menumbuhkan Kembangkan Karakter Bangsa. Seminar Nasional Hukum.

Wasithohadi, 2019, Aktualisasi Nilai-Nilai Pancasila Di Era Global Antara Harapan Dan Kenyataan, Makalah Tidak Dipublikasikan. 